\title{
Changing inland waterbody livelihoods in Issyk-Kul, Kyrgyzstan
}

\author{
Michael Fabinyi (corresponding author) \\ University of Technology Sydney, Australia \\ michael.fabinyi@uts.edu.au
}

\section{Ian Phil Canlas}

University of Central Asia, Naryn, Kyrgyzstan

ian.canlas@ucentralasia.org

\author{
Philip Hayward \\ University of Technology Sydney, Australia \\ philip.hayward@uts.edu.au
}

\author{
Samat Kalmuratov \\ University of Central Asia, Naryn, Kyrgyzstan \\ samat.kalmuratov@ucentralasia.org
}

Publication Information:

Received 20 January 2020, Accepted 29 March 2020, Available online 29 June 2020

DOI: $10.21463 /$ jmic.2020.09.1.02

\begin{abstract}
This paper examines livelihood transition along inland waterbodies, drawing on secondary literature and interviews to examine a case study of Issyk-Kul, a large Lake in Kyrgyzstan. Livelihood activities along Issyk-Kul are diverse and seasonal, and include fruit, vegetable and cereal farming, livestock management and pastoralism, tourism, remittances and fisheries and aquaculture. We focus in depth on tourism and fishing. While both activities have fluctuated in significance over many decades; overall, we show how tourism is increasing while fisheries have drastically reduced. We argue that livelihood activities in Issyk-Kul are characterised by the increasing importance of both discursive and material connections beyond the Lake itself, and identify areas for future research on livelihoods along inland waterbodies.
\end{abstract}

\section{Keywords}

Inland waterbody, lake, livelihoods, Issyk-Kul 


\section{Introduction}

A major theme in the extensive literature on rural agrarian change is that of livelihood transition, a process by which small-scale farmers move away from work on the farm to more mobile, diverse and complex livelihoods (Rigg, 2006; Tubtim and Hirsch, 2017). The classic 'agrarian question' of the extent small-scale peasant farmers either persist or become 'proletarianised' wage labourers continues to be discussed (Eder, 1993; Bernstein, 1996; Akhram-Lodi and Kay 2010a, 2010b). More recent discussions relating to livelihood transition also examine: how livelihoods are affected by new forms of enclosure such as 'land grabbing' (including 'green grabbing') (Borras et al., 2011; Fairhead et al., 2012), government programs of land reform (Borras and Franco, 2010) and the role of the state (Bebbington, 2000), changing demographics of migration and urbanisation (Kelly, 2011; Rigg et al., 2012), and social processes of exclusion (Hall et al., 2011). Yet, in such research a significant terrestrial bias persists (Dressler and Fabinyi, 2011; Campling et al., 2012). Through a case study of livelihood transition along Lake Issyk-Kul (hereafter Issyk-Kul ${ }^{1}$ ), Kyrgyzstan, this paper aims to stimulate discussion about the extent and characteristics of livelihood transition along inland waterbodies.

An emerging body of research has adapted questions from the terrestrially-focused literature on agrarian change to studies along coastal regions, with an emphasis on fisheries. As Idrobo and Johnson state, globalised change is "driving transitions in small-scale tropical fisheries away from natural resource-based livelihoods towards wage labour that involves employment in the service industry and outmigration from centres of origin" (Idrobo and Johnson, 2019: 67). For instance, researchers have discussed how the biophysical characteristics of oceans have implications for the expansion of capitalism (Campling et al., 2012; Campling and Colás, 2018; Foley and Mather, 2019); the emerging phenomena of 'coastal grabbing' (Bavinck et al., 2017) and 'ocean grabbing' (Bennett et al., 2015); and the nascent 'blue economy' that aims to reconcile wealth generation with environmental sustainability (Childs and Hicks, 2019). There have also been discussions of the challenges and opportunities presented by the specific livelihoods that coastal residents are transitioning into, notably tourism (Knudsen, 2012; Porter et al., 2015; Fabinyi, 2019; Idrobo and Johnson, 2019), aquaculture (Belton and Thilsted, 2014, Bush and Marschke, 2014; Belton et al., 2017), intensified forms of fishing activity (Fabinyi, 2010, Betcherman and Marschke, 2016) and urbanised livelihoods (Knudsen, 2016; Kadfak, 2019).

Attention to livelihood changes along inland waterbodies is increasing, concentrating on the role of fisheries (e.g. Hap et al., 2006; Neiland and Béné, 2008; Thorpe and van Anrooy, 2009; Lynch et al., 2016; Funge-Smith, 2018; Song et al., 2018; Funge-Smith and Bennett, 2019). This research aims to address the point that such 'forgotten' (Cooke et al., 2016) inland fisheries are in many cases less well-understood than those of their maritime counterparts, despite their huge economic, social and environmental significance (Funge-Smith, 2018). In addition to estimates of their value and contributions, one of the important insights of this emerging work is to highlight how inland fisheries are mostly dispersed and small-scale, and mostly part-time and integrated with other livelihood activities, with significant intersectoral linkages (Song et al., 2018; Funge-Smith and Bennett, 2019). However, more generally, the study of livelihood change along inland waterbodies - including, but not limited to fisheries - is much less, compared to that of coastal livelihood change. While Song et al. (2018) focus on the implications of intersectorality in inland fisheries for their governance, we focus on the implications of the multi-sectoral nature of inland waterbody livelihoods for livelihood change more broadly.

The study of freshwater systems is dominated by natural science perspectives. A recent definition of 'global limnology', for example, refers to "quantifying and understanding the role of continental waters in the functioning of the biosphere" (Downing, 2009: 1149), while a recent assessment of ten problems facing limnology has a strong natural science focus 
(Downing, 2014). While much research in limnology has an implicit connection to humans, for instance through examining overfishing and pollution, detailed studies of the ways in which humans use and relate to these inland waterbodies - their human ecology - are far fewer (although with exceptions, see e.g. Horwitz et al., 2001; Ruddle and Satria, 2010; Kawanabe et al., 2012). Again, the broader human ecology of maritime communities compared to inland waterbodies is far better represented in the literature (e.g. Acheson, 1991; King and Robinson, 2019, the journals Journal of Marine and Island Cultures, Marine Policy, Maritime Studies, Ocean and Coastal Management and Shima). Overall, relative both to studies of coastal livelihood transitions and to natural scientific knowledge about inland waterbodies, there is a dearth of studies of livelihoods along inland waterbodies, and how they are changing.

Addressing this gap in the literature, this paper examines the question of the extent and nature of how inland waterbody livelihood activities are changing, using the case study of Issyk-Kul in Kyrgyzstan. Recognising the various critiques of much of the literature on livelihoods (e.g. De Haan and Zoomers, 2005; Carr, 2013; McLean, 2015) for being overly concerned with the logics of economic behaviour, rational action and for the lack of attention to power dynamics, for the purposes of this paper we focus on the relatively narrow component of how livelihood activities are changing. Specifically, we emphasise how the fluctuating importance of fisheries and the increased importance of international tourism is representative of a broader shift towards globalised, transnational livelihoods.

\section{Methods}

The research for this paper involved a combination of interviews and use of secondary material. Existing secondary literature, including published academic literature, unpublished academic theses, reports and legislation was examined, and forms the basis of much of the analysis. An initial field trip was conducted in August 2018, undertaking informal interviews and observations on livelihood activities around Issyk-Kul. More detailed semi-structured interviews took place in March-April 2019, and in September 2019. Interviews focused on questions relating to how livelihoods have been changing over time: both within households, and at a more general scale along the lake, with a focus on to what extent and how they are changing. We conducted interviews both along the northern sides of the lake (around CholponAtta and Bosteri) and on the southern (around Kajisay). Interviewees included men and women involved in tourism, fishing, aquaculture, crop farming, livestock management, trading, and in government or government body positions. Interviewees were asked not only for their own personal experiences but in many cases were key informants who had broader knowledge of livelihood change. Overall, 23 interviews were undertaken. Fieldnotes were undertaken and subsequently analysed through the identification of dominant themes (Bernard, 2017). The paper presents some initial findings and aims to pose questions about the nature of livelihood change along Issyk-Kul and inland waterbodies more generally. 


\section{Livelihood Activities in Issyk-Kul}

Kyrgyzstan is classified as a lower middle-income country according to the World Bank; it has a GDP in 2018 of US\$8.1 billion, a GNI per capita of US\$1220, and in 2017 a population of 6.3 million (World Bank, 2019). Livelihoods in Kyrgyzstan have historically been strongly associated with transhumance, or seasonal movement of livestock (Petric, 2015). Kyrgyzstan was annexed by the Russian Empire in 1876 and subsequently incorporated into the Soviet Union. With the collapse of the Soviet Union in 1991, the Kyrgyzstan economy underwent dramatic changes involving rapid privatisation, including that of the kolkhoz (collective farming) system, which generated many economic challenges. Relative to its Central Asian neighbours (i.e. Kazakhstan, Tajikistan, Turkmenistan, and Uzbekistan), Kyrgyzstan is considered to be more economically and politically open, and has become a regional hub for international development organisations and transnational networks (Petric, 2015).

Although a landlocked country, inland waterbodies play a significant role in Kyrgyzstan's economy and society. For example, extensive ethnographic work over many years, (e.g. Féaux de la Croix 2011, 2015; Wooden and Féaux de la Croix, 2017) has shown how dams and rivers are important not only by their potential and real role in the production of hydroelectricity (e.g. the Toktogul Dam), but also in a symbolic way, for example through the association of flowing water with the concept of tazalyk (purity, hygiene, uprightness). The Naryn River flows for $807 \mathrm{~km}$, and there are several lakes in the country, the largest of which (by far) is Issyk-Kul.

Issyk-Kul (Fig. 1) has a surface area of $6240 \mathrm{~km}^{2}$ and lies at an altitude of $1608 \mathrm{~m}$ (Mikkola, 2012). It is considered to be the second highest mountain lake and the fifth deepest lake in the world (Mikkola, 2012; Thorpe et al., 2009). The surrounding mountains of Ala-Too (part of the Tian Shan range) to the north and the south of the Lake provide most of its water. The Lake holds a great deal of cultural significance in Kyrgyzstan and there are numerous holy sites along it (Asanova, 2002; Samakov and Berkes, 2017). The Lake lies within Issyk-Kul Region (oblast) (see Fig. 1). The northern side of the Lake has a series of waterside settlements, the largest of which are Cholpon-Ata (population c10,500) and Bosteri $(c 7,400)$, while the settlements on the southern side of the Lake, such as Kajisay $(c 4,200)$ and Bokonbaev $(c 10,650)$, are set back from its shores. The capital of the Issyk-Kul Region, Karakol (c67,000), is located eight kilometres inland on the central eastern side. In relation to the geographical and ethnic divides between north and south in Kyrgyzstan (which are implicated in much civil unrest in recent years - see e.g. Gullette and Heathershaw, 2015; Ismailbekova, 2017), the Issyk-Kul Region is considered to be part of the north and has not experienced such disturbances although the region also has amongst the highest indices of village poverty in the country (Thorpe and van Anrooy, 2009). 


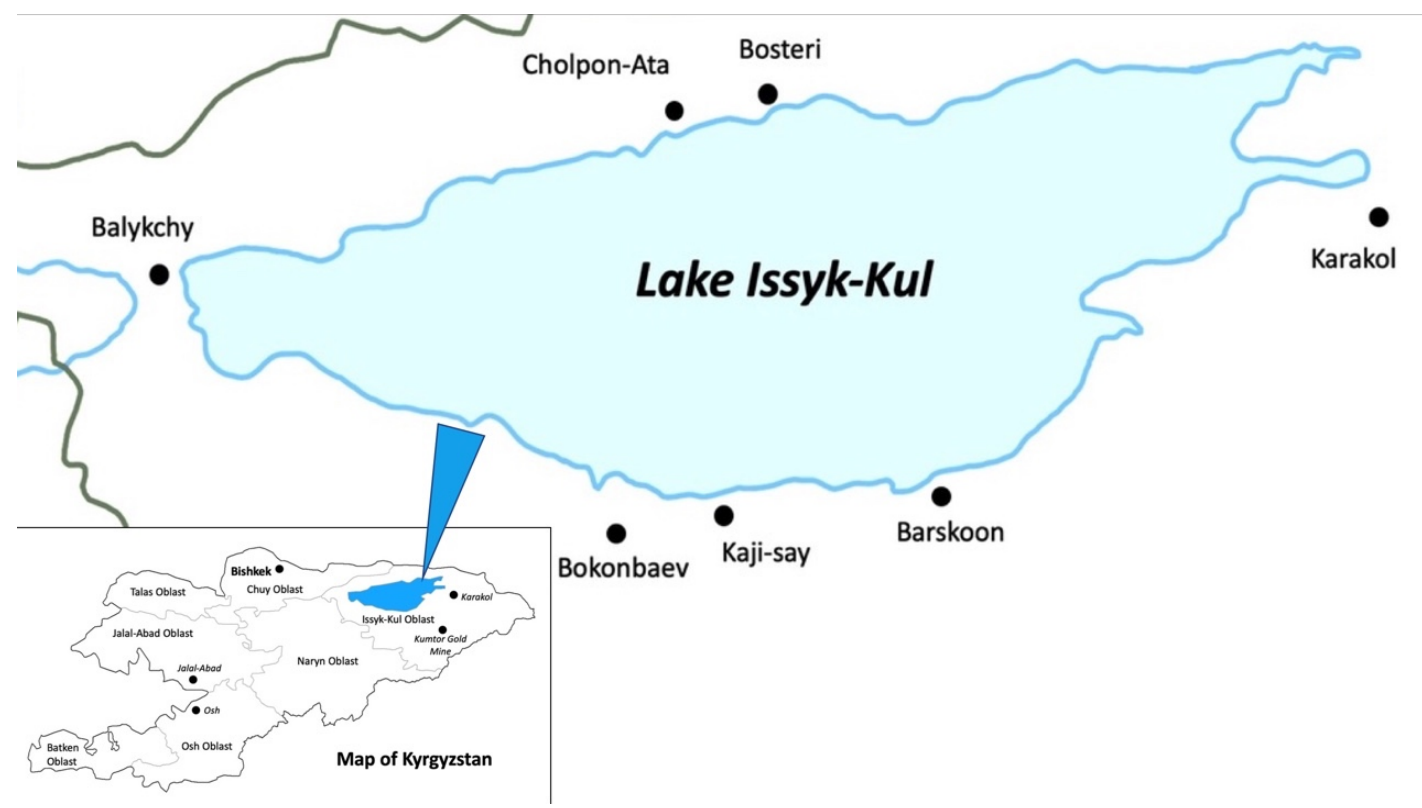

Fig 1. Map of Issyk-Kul and its surrounds. (Ian Phil Canlas, 2019)

Livelihood activities along the lake have changed considerably over the last century, and can be roughly grouped into four main categories: agriculture and livestock, remittances, tourism, and fisheries. Historically, agriculture and livestock (particularly cattle) were very common. During the post-Soviet transition period, existing systems of governance and the economy were rapidly transformed. Our field research identified that major crops currently grown around the Lake include fruits such as apples, apricots, peaches, pears, blackcurrants and cherries, vegetables such as potato, garlic and carrot, and cereals such as barley. In the hills behind the Lake, livestock - sheep, horses, cows, goats and chickens are raised. Various dairy products and fermented drinks (e.g. maksym) are also produced.

Cattle are raised in pastures in summer, returning to low lying areas in the autumn for wintering. While transhumance remains a very important livelihood activity, the organisation and governance has changed considerably (Farrington, 2005). There are an increasing number of non-government organisations from overseas working to improve pasture management. Among the international organizations working related to livelihood development around Issyk-Kul are the German Federal Enterprise for International Cooperation (GIZ), the United Nations Development Programme, the Organization for Security and Co-operation in Europe, the Asian Development Bank, and the Aga Khan Development Network. Interviewees suggested that the majority of agriculture and livestock activities were previously for family consumption, but are now orientated more towards trade. Animals are usually brought to Tokmok or Karakol, while fruits such as apricots and apples are sold to regional centres and Bishkek or exported to Kazakhstan and Russia. Usually traders from these countries will bring refrigerated trucks to load up the product. Other products are sold to local hotels and guesthouses around Issyk-Kul. Summer and autumn are harvest seasons; spring is a difficult time because of a lack of resources, and during winter there is generally not much activity because of the extreme cold (average January temperatures around Issyk-Kul are around $-10^{\circ} \mathrm{C}$ ).

Many households in Bokonbaev, Kajisay and other settlements along the southern side of the Lake obtain remittances from family members who work at the Kumtor open-pit mine, which commenced operating in 1997. The mine employees around 2600 Kyrgyz nationals and provides approximately $8.6 \%$ of the country's GDP (Kumtor, 2019) and has been seen 
as a crucial site for the development of "resource nationalism" in Kyrgyzstan (Fumagalli, 2015). It has also generated environmental concerns, in particular related to an incident in 1998 involving a truck crash that spilled 1.7 tons of sodium cyanide, which subsequently impacted rivers flowing into Issyk-Kul (Akçali, 2015; Horrocks-Taylor, 2018). Other households have family members who work in Bishkek, Kazakhstan, or Russia. Throughout Kyrgyzstan, migration to Russia has increased significantly since the removal of state restrictions on movement. Petric suggests that in the last few years, "the Kyrgyz, who sweep the streets, build new buildings, and work as porters on the markets, have become the new proletariat in Russian society, along with Uzbeks and Tajiks" (2015: 80).

Many households hold diverse livelihood portfolios, practicing several livelihood activities within the household simultaneously, or in different seasons. We explore below how livelihood activities have involved an increasing emphasis on building connections beyond the Lake itself through more detailed accounts of tourism and fishing. International tourism has become more important, while fisheries has had fluctuating significance and is currently not a major livelihood activity.

\section{Tourism}

Tourism in Kyrgyzstan has been strongly promoted by the government and pursued by households in the post-Soviet era (Palmer, 2009; Akçali, 2015). Efforts to promote tourism typically concentrate on Kyrgyzstan's natural assets and cultural traditions (Petric, 2015). The tourism sector grew in the 1960s and 70s, then dipped after Soviet withdrawal, and rose significantly during the 1990s and 2000s. However, it has slowed or stagnated since 2011 (Jenish, 2017). Major challenges facing the tourism sector include poor transport infrastructure, limited knowledge of English among the population, political instability and occasional civil unrest, and what Jenish (2017) describes as 'mediocre' tourism promotion efforts by the government. The Department of Tourism under the Ministry of Culture, Information and Tourism is responsible for all tourism related matters in Kyrgyzstan, including Issyk-Kul. Local government counterparts, i.e. the ayil okmotu, are also responsible at the local level.

During the Soviet era, Issyk-Kul was a favoured spot for Russians. In particular, plush resorts on the northern side of the Lake were regularly frequented by Party elites (Palmer, 2009). One resort at Cholpon-Ata became an official summer residence for the Kyrgyz president, and former Russian president Boris Yeltsin was another high-profile regular visitor (Palmer, 2009: 189). The perception within Kyrgyzstan is that tourism to Issyk-Kul has increased significantly over the past decade, and while figures are not clear, one report suggests that Issyk-Kul accounts for about $90 \%$ of tourism receipts for the entire country (Jenish, 2017). Just as Kyrgyzstan is marketed as 'the Pearl of Central Asia', Issyk-Kul is marketed as the 'Pearl of Kyrgyzstan' (Lonely Planet, 2019). Most tourists are from Russia and Kazakhstan (Palmer, 2009; Jenish, 2017), as well as some domestic Kyrgyz tourists, but interviewees anecdotally reported a small but increasing trend of tourists coming from countries further afield including Turkey, China, North America and Europe (which corresponds to overall data on national tourism trends, see Jenish, 2017: 12).

Most tourism is concentrated on the northern side of the Lake, where many resorts are located, especially in and around the towns of Cholpon-Ata and Bosteri. Resorts around Issyk-Kul charge, on average, US\$100 per night for a standard room (Jenish, 2017 and our 2019 field observations). The major activities tourists are involved in are beach tourism and spa/sanatorium-type services. Jenish argues that while Issyk-Kul has excellent natural assets, the 'price-quality ratio' is very high compared to similar destinations in Turkey and Spain. The construction of new resorts is strongly visible along the main highway, and construction work provides a significant source of employment in the region. The World Nomad 
Games have been hosted in Cholpon-Ata in 2014, 2016 and 2018 and, in preparation for the most recent Games, a huge stadium complex was built.

There is an absence of (operating) high-end resorts on the southern shore of Issyk Kul and the area is generally underdeveloped and more peaceful than the north (Fig. 2). On this side of the Lake, there is a greater emphasis given to more low-key types of tourism such as ecotourism and jailoo tourism, which involves staying in summer pastures that surround the Lake. Furthermore, while developed areas of the northern shore are dominated by tourists from the former USSR (principally from Russia and Kazakhstan), local informants suggested that the southern shore seems to appeal more to tourists from Europe and North America (a proposition that requires further research). This may be interpreted as evidence of the dichotomy that Palmer (2009) identified as "a dilemma over attempting to maintain ties with Soviet era Central Asian neighbours versus becoming an independent nation within a wider international community" (2009: 193).

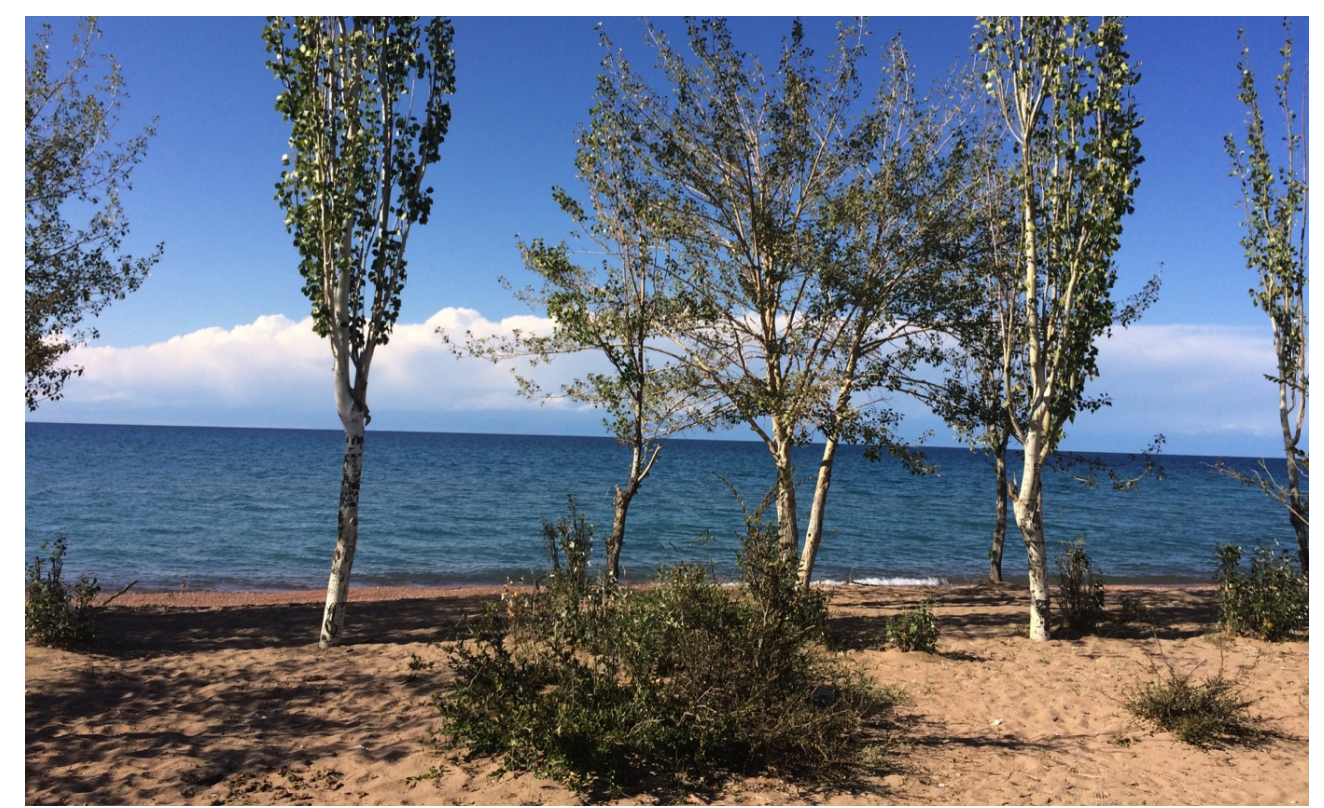

Fig 2. View north from south side of Issyk-Kul, near to Kadzhi-Sayskiy Plyazh. (Photograph by Philip Hayward, 2019)

In addition to state promotion, support and regulation, tourism also develops very organically. Homestay accommodation, for example, is very common. Households will convert a small portion of their land into e.g. a cottage that is then rented out on a casual basis. One household interviewed in Kajisay, for example, built a cottage out the back of their house in 2014, and with the money generated from this cottage saved and built a new cottage (with better facilities, such as a private bathroom) in 2018. Another household interviewed noted that they had opened a guesthouse in 2018, and subsequently earned about KGS400,000 (about US\$5700) in one season, between July-October. Tourism also supports other livelihood activities. For example, one household we encountered during research has their poultry products bought by or delivered to restaurants and guesthouses in Cholpon-ata and Bosteri, a common practice particularly in summer and spring when the demand is high. In winter it is too cold for most tourists. 
Fed by increasing demand for agriculture and tourism, land prices have been rising rapidly in recent years. For example, 1ha (10,000 square metres) of agricultural land cost about KGS70000 (approx. US\$1000) in 2014, but by 2019 cost approximately KGS120,000 (approx US\$1715). Land by the lake currently costs considerably more, square metre plots selling between KGS 42,000-70,000 (US\$600-1000) depending on proximity to prime tourism locations (data supplied by University of Central Asia Institute for Public Policy and Administration, January 2020).

Overall, the increase in tourism has provided significant livelihood opportunities, both for those directly in the tourism sector (e.g. accommodation, guiding, restaurants) and for those whose work is indirectly supported through increased demand for construction and agricultural products. Kozhokulov et al. (2019) forecast stronger growth for the tourism sector for the Issyk-Kul Region in coming years, and suggest that tourism generates strong positive economic and social impacts. More detailed social analysis that attempts to understand how these changes, particularly in relation to rising land prices and sales, articulate with existing forms of social differentiation relating to e.g. class, gender and ethnicity will be an important area for future research.

\section{Fishing}

Prior to the Russian annexation of Kyrgyzstan in the late $19^{\text {th }}$ century, its occupants were predominantly nomadic. The groups who moved around Issyk-Kul had little if any tradition of fishing and did not regard fish as an attractive food source, even in times of food scarcity, and consequently lacked fishing skills and broader knowledge of the lake's ecology. The Russians who arrived in the area in the 1870s were more interested in and able to fish in the lake and did so for food, catching native fish, primarily for local consumption and commercial harvesting for local sale to Russian communities in Karakol at the eastern end of the lake and in Bishkek. From the late $19^{\text {th }}$ century until 1930, fisheries catches in Issyk-Kul were dominated by the capture of Issyk-Kul dace (Leuciscus bergi), 'chebachok', with catches from Issyk-Kul rising to 1000 tonnes annually (Thorpe et al. 2009). The city of Balykchy was originally called Ribache; ('fishing place' in Russian) and after independence to Balykchy ('fisherman' in Kyrgyz).

In 1930 eggs of the Sevan trout (Salmo ischchan) from Lake Sevan in Armenia were released into the Lake and hatcheries set up in surrounding rivers for restocking programs (Thorpe et al. 2009). The Sevan trout adapted extraordinarily well to Issyk-Kul, growing to a larger size and with a growth rate 4 to 6 times as fast as in Sevan Lake (Mikkola, 2012, see also Romanovsky, 2002). Other non-native species were also introduced, notably rainbow trout (Onchorhynchus mykiss), and by the 1960s total annual production had increased to more than 1000 tonnes (Thorpe et al., 2009). This, in turn, served as an attraction for Russian visitors to the area, who particularly congregated around early tourism facilities on the north shore, consuming local fish and also engaging in recreational fishing from the shore and small boats. Despite competition between species, in interviews conducted by the authors in 2019 locals recalled that the lake - and its southern shores in particular (which were not visited by tourists or commercial fishers) - had ample fish resources in the 1980s and 1990s and that some families, at least, caught fish through line fishing or scooping fish from shallows to supplement their predominantly meat-based diet. However, due to a combination of overfishing in the lake and in the rivers and streams feeding into it, and the predation of native species by non-native species, fisheries collapsed and by 1990 fisheries production from the Lake was just $20 \%$ of its peak in 1965 (Niyazov, 2007; Thorpe et al, 2009; Graham et al., 2017).

Our interviews with staff of the Governmental Agency for Environmental Protection (GEAP) suggest significant changes occurred after independence in 1991, when the Issyk-Kul Region experienced a rapid economic decline and related food 
shortages. Local populations around the lake began to fish to sell their catches and, in some instances to supplement their diets. The intensity of this activity rapidly reduced the fish biomass of the lake, with fishers indulging in a familiar pattern of continued fishing (and of catching increasingly smaller and younger fish) despite the clear dwindling of the resource. Concern about this activity eventually led to the declaration of a moratorium on net fishing in 2006 that was subsequently extended and operated through to early 2019. The operation of fish pens in the lake was also terminated. During this time pole fishing for personal consumption was allowed. The moratorium was controlled by GEAP inspectors as well as by local governments around the lake. GEAP representatives identified this as a challenging task, given their minimal resourcing, limited staff and the large size of the Lake. There was limited understanding and acceptance of the moratorium and much illegal fishing (see also Mikkola, 2012).

The moratorium was finally withdrawn in 2019 following pressure from the Issyk-Kul Biosphere Reserve (IKBR) administration. The IKBR was established as a UNESCO accredited biosphere reserve in 2001, administering the lake, its shores, surrounding mountain ranges and the rivers that crossed these. ${ }^{2}$ Acting on advice from its Fisheries office, the IKBR lobbied for the moratorium to be lifted on the grounds that in over a decade it had had not resulted in any increase in fish stocks, and particularly of native fish. Instead the IKBR has been granted the right to issue licences for commercial fishing of non-native species (only) as a conscious measure to reduce their presence in the lake and allow native fish to recover. It is notable in this regard that the introduced fish identified as the most avaricious predator on native fish stocks, the rainbow trout, has itself substantially dwindled, a situation attributed to the consumption of fish eggs and fry by a species of introduced catfish (likely Turkestan catfish, Glyptosternum reticulatum [Mikkola, 2012]), which is now identified as the most dangerous predator by IKBR and encourages fishermen to catch it. In interviews the IKBR asserted that during the 1980s Russian researchers identified 36 types of fish in the region whereas recent IKBR surveys have only identified 21 .

Our field research suggests that the historic association of lakes with fish, and of Issyk-Kul with fish, particularly during the Soviet and independence eras, has led local entrepreneurs to offset the shortage of fish in the lake by both importing fish from Russia to sell in dried form along roadsides and to feature in café menus. Such history may also have been a factor in the establishment of fish farming operations (primarily producing rainbow and golden trout [Oncorhynchus aguabonita]) in locations around the lakeshore and (briefly) in fish pens on the southern shore of the lake. The IKBR identified to us that there were 83 fish farms operating in the IKBR area in late 2019 . These are carefully monitored by regional authorities, at least with regard to their initial construction, and are not permitted to be immediately adjacent to the lakeshore. Some - such as the Ala-Balyk Trout Farm, on the north eastern corner of the lake (Figs. 3 and 4) - have combined substantial fish cultivation activities, supplying local and Russian markets, and tourism, allowing tourists to identify and catch fish for later consumption or for cooking in the site's kitchens. While local informants suggested to us that there has been an increase in local consumption of fish (by those affluent enough to buy it (it is substantially more expensive per kilo than lamb, for instance) there appears to be no evidence that its consumption is widespread. 


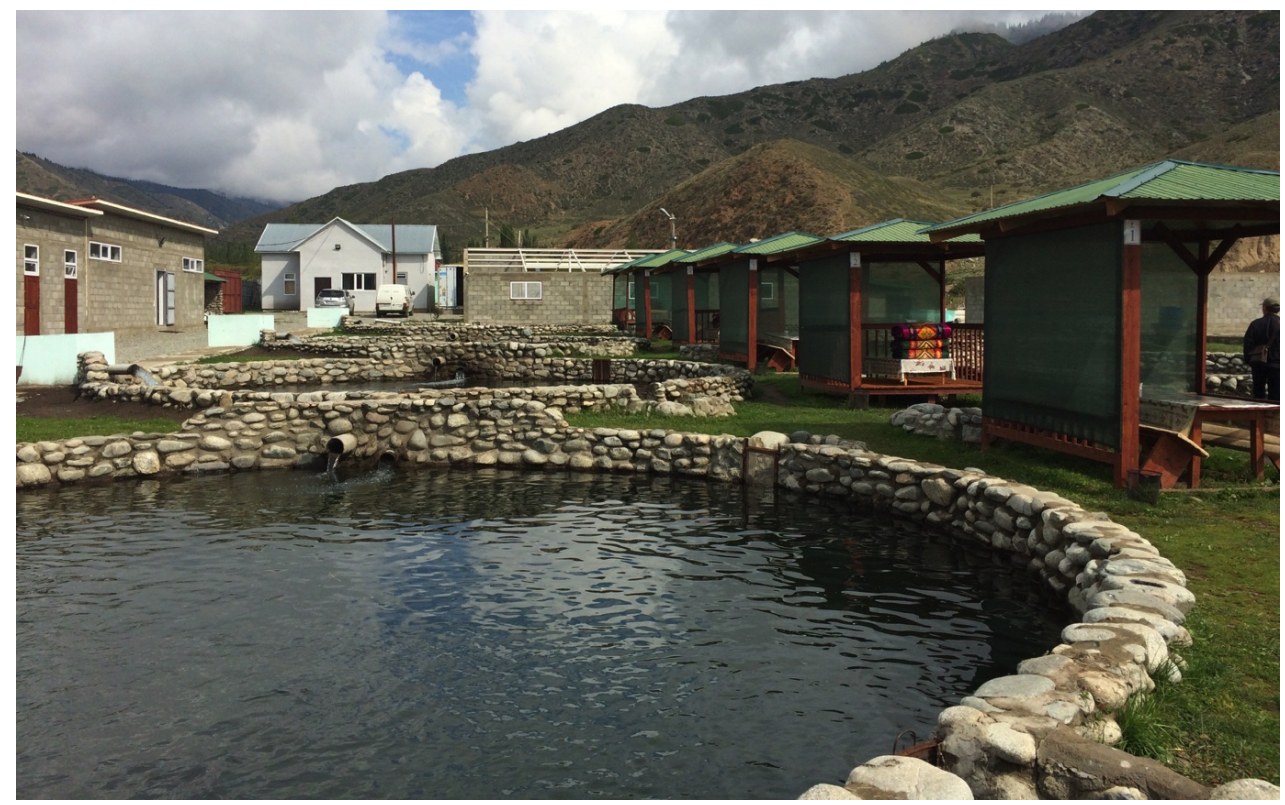

Fig 3. Ala-Balyk Trout Farm (showing sheltered kiosks on right hand side where patrons can eat fish from the pens). (Photograph by Philip Hayward, October 2019.)

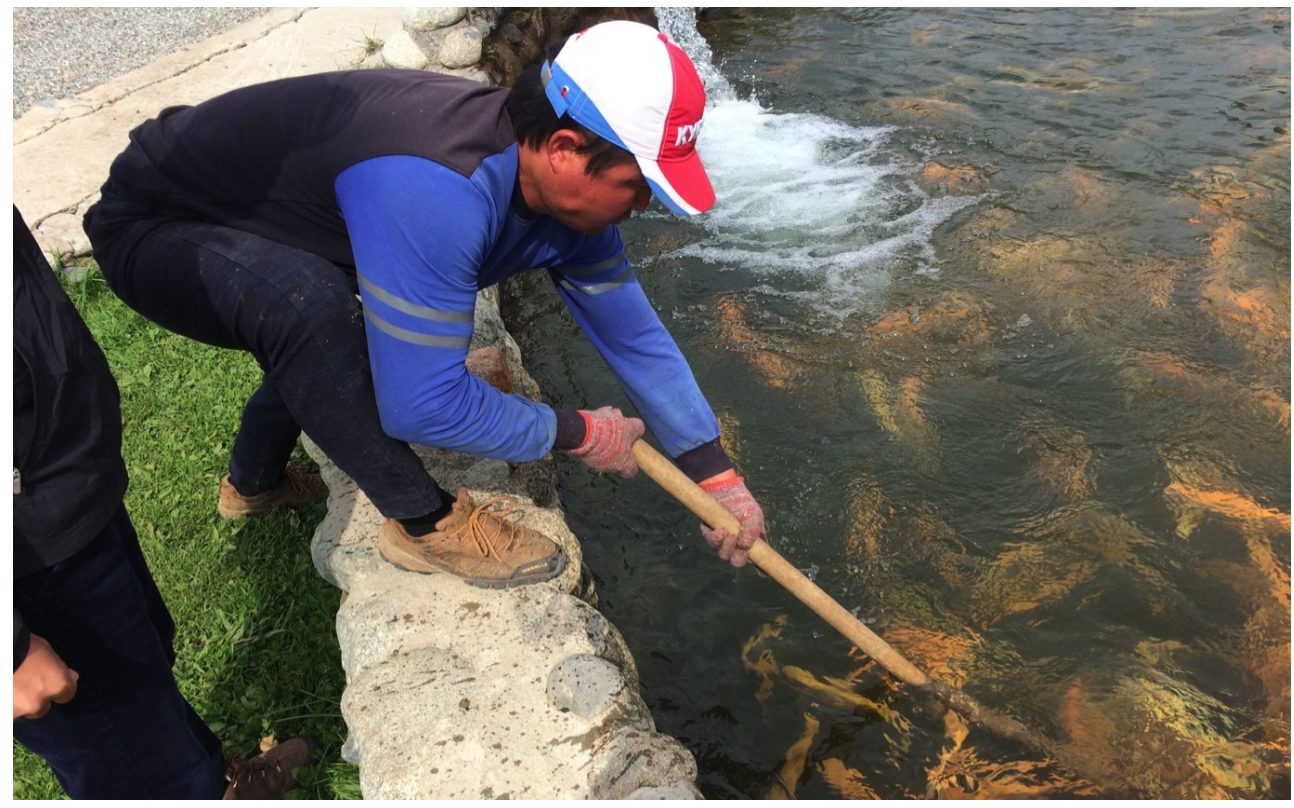

Fig 4. Worker netting trout for customers to consume on-site at Ala-Balyk Trout Farm. (Photograph by Philip Hayward, October 2019.)

The IKBR identified no particular view concerning future use of the lake once/if native fish stock are substantially restored to us, identifying the restoration activity as their prime concern and leaving the management and regulation of leisure and/or commercial fishing to the regional and national authorities to decide. One thing that was evident from interviews with IKBR personnel, fish farm operators and managers is that the maintenance of the lake and surrounding region as an under-developed and minimally damaged environmental system is seen as important and as a source of 
local and national pride and as a key tourism attractor in coming decades. Lake rehabilitation is perceived as one key aspect of this.

Interestingly, no one interviewed by the authors (on or off the record) identified pollution of the Lake's water by industrial, mining or residential developments as a significant factor in either the general ecology of the Lake itself or of its fish stocks. Several informants also identified that the cumbersome and multi-staged local and regional bureaucratic processes necessary to build various structures around the lake (processes of the type typically bemoaned by Kyrgyz) serve to provide high scrutiny of all proposals. This combines with the responsibility of architects, developers, builders and commercial operators to have conformed to guidelines that might adversely impact the lake (Nippon Koei, 2009). The IKBR regard the existing gold mine at Kumtor as a potential problem, and is monitored to this end, and proposals to build uranium extraction operations in other areas have also been opposed by the IKBR.

Overall, fishing has declined in significance for the Lake itself, and in particular, endemic fish have hugely declined and largely been replaced by non-native species. Yet Issyk-Kul has maintained important associations with fishing through aquaculture farms nearby and through trade.

\section{Discussion and Conclusion}

Authors discussing agrarian change have long examined how, among others, key processes of globalisation, mobility, and urbanisation influence livelihoods in rural spaces (Rigg, 2006; Rigg et al., 2012; Tubtim and Hirsch, 2017). At IssykKul, similar processes can clearly be observed, as is the case with Kyrgyzstan more broadly (Petric, 2015). Livelihood activities have involved an increasing emphasis on building material and discursive connections beyond the Lake itself. This can be seen in the expanded rate and scale of the flow of goods, the continuing importance of migration and remittances and increasing international tourism.

It is important to note that while we have identified the increasing importance of extra-local linkages, these linkages do not always neatly map on to assumptions about peripheries being incorporated into core or centre regions: common orientations in much of the broader literature on international development, whether from a critical (e.g. Harvey, 2014; Hornborg and Crumley, 2016) or more positive perspective (e.g. Gereffi, 1999; Gereffi et al., 2005). While this process can certainly be seen through, for example, the increased association of livelihood activities around Issyk-Kul with international markets, in other cases building connections beyond the Lake reflects more the construction of 'transperipheral networks' of specific resources that are not linked to the centre (Kuwahara et al., 2007). For example, Issyk-Kul serves as a location for the import of fish (specifically rainbow trout) from aquaculture farms elsewhere in the country to service tourists expecting the product. Lakes can be therefore connected to other (peripheral) inland and maritime fisheries through commodity supply chains. Similarly, local networks of kinship and customary governance (Reeves, 2014; Beyer, 2016, Ismailbekova, 2017) are important locally grounded factors that substantively affect the governance of and differential outcomes associated with livelihood change (Pickles and Smith, 2016; Werner, 2018).

We have focused in this paper in particular on the role of tourism and fisheries. While tourism from former Soviet countries remains dominant, tourism forms part of the Kyrgyz government's broad strategy of opening the country up to wider influences. As mobility and globalisation increases, it is likely that tourism will continue to influence livelihoods in 
Issyk-Kul. Key questions to assess will be how the costs and benefits of tourism are distributed among different members of society, in particular, how rising land prices affect the ability of local residents to obtain benefits from the increase in tourism. A second key issue will be the ability of the authorities to maintain the environmental values of Issyk-Kul, which form the basis for its tourism appeal. This challenge is reflected in the dramatic declines of fisheries from Issyk-Kul. Capture fisheries in Issyk-Kul are now a peripheral livelihood activity, which will likely require many years of effective protection before they can become viable again.

Around Issyk-Kul, livelihood activities have modified since independence. While this poses challenges when seeking to draw broader conclusions or insights about the nature of livelihood change along inland waterbodies, we suggest that Song et al.'s (2018) discussion of intersectorality is useful here. In their review paper on inland fisheries, they argue that given the typical connections of inland fisheries to other livelihoods and to other uses of inland waterbodies, intersectorality is a key concept that needs to be placed at the forefront of any analysis. Inland fisheries, they suggest, tend to be affected by other sectors to a greater degree than their maritime counterparts (see also Funge-Smith and Bennett, 2019). Around Issyk-Kul, the diversified and multi-sectoral nature of livelihood activities has meant that different livelihood activities have fluctuated significantly over time. In this sense, the diversified livelihood portfolios held by some households may have served to mitigate risk and lower levels of vulnerability to changing economic, environmental and seasonal circumstances (Ellis 2000; Martin and Lorenzon, 2016).

Tracing the implications of the intersectoral or diversified nature of inland waterbody livelihoods in greater depth for livelihood outcomes would be a useful exercise to pursue in future research. For example, what is the relationship between levels of diversification in inland waterbody livelihoods and levels of wealth and wellbeing? How does diversification articulate with local social and cultural norms and customary forms of governance? Other key questions it would be useful to examine in greater depth include the extent, drivers and outcomes associated with tourism along inland waterbodies; tensions and areas of complementarity between environmental and spiritual values ascribed to inland waterbodies and their contemporary use and governance. In particular, addressing the implications of regional and global environmental change, including climate change, for livelihoods along inland waterbodies will be important to ensure that inland waterbody livelihoods can continue to support sustainable livelihoods into the future.

\section{Acknowledgements}

The authors wish to thank Mark Evans and Destiny Wolf from University of Technology Sydney, and Diana Pauna and Marc Foggin from University of Central Asia for helping facilitate this research around Issyk-Kul.

\section{Endnotes}

1. 'Kul' is a Kyrgyz term that means both 'lake' and, more generally, a large expanse of something.

2. http://www.unesco.org/mabdb/br/brdir/directory/biores.asp?mode=all\&code=KIZ+02 


\section{References}

Acheson, James, M., 1981. Anthropology of fishing. Annual review of anthropology, 10.1: 275-316.

Akçali, P. 2015. Tourism in Kyrgyzstan. In Kantarci, K., M. Uysal and V. Magnini (eds), Tourism in Central Asia: cultural potential and challenges, Toronto and New Jersey, Apple Academic Press: 259-286.

Akram-Lodhi, A. Haroon and Kay, Cristobal. 2010. Surveying the agrarian question (part 1): unearthing foundations, exploring diversity. The Journal of Peasant Studies, 37(1), pp.177-202.

Akram-Lodhi, A. Haroon and Kay, Cristobal. 2010. Surveying the agrarian question (part 2): current debates and beyond. The Journal of Peasant Studies 37.2: 255-284.

Alamanov, A. and Mikkola, H., 2011. Is biodiversity friendly fisheries management possible on Issyk-Kul Lake in the Kyrgyz Republic? Ambio40.5: 479.

Asanova, Umut. 2002. Philosophy of ecological ethics education, considering the Issyk-Kul lake remediation mechanisms. In Klerkx, Jean and Imanackunov, Beishen (eds), Lake Issyk-Kul: Its Natural Environment, Dordrecht: Kluwer Academic Press: 263-267.

Bavinck, Maarten, Fikret Berkes, Anthony Charles, Ana Carolina Esteves Dias, Nancy Doubleday, Prateep Nayak, and Merle Sowman. 2017. The impact of coastal grabbing on community conservation - a global reconnaissance. Maritime Studies 16.1: 8.

Bebbington, Anthony. 2000. Reencountering development: Livelihood transitions and place transformations in the Andes. Annals of the Association of American Geographers 90.3: 495-520.

Belton, Ben and Thilsted, Shakuntala Haraksingh. 2014. Fisheries in transition: Food and nutrition security implications for the global South. Global Food Security 3.1: 59-66.

Belton, Ben, van Asseldonk, Imke and Bush, Simon R. 2017. Domestic crop booms, livelihood pathways and nested transitions: charting the implications of Bangladesh's Pangasius boom. Journal of Agrarian Change 17.4: 694-714.

Bennett, Nathan James, Hugh Govan, and Terre Satterfield. 2015. Ocean grabbing. Marine Policy 57: 61-68.

Bernard, H. Russell. 2017. Research methods in anthropology: Qualitative and quantitative approaches. Lanham, MD: Rowman \& Littlefield.

Bernstein, Henry. 2006. Is there an agrarian question in the 21 st century? Canadian Journal of Development Studies/Revue canadienne d'études du développement 27.4: 449-460.

Betcherman, Gordon and Marschke, Melissa. 2016. Coastal livelihoods in transition: How are Vietnamese households responding to changes in the fisheries and in the economy? Journal of Rural Studies 45: 24-33.

Beyer, Judith. 2016. The force of custom: Law and the ordering of everyday life in Kyrgyzstan. Pittsburgh: University of Pittsburgh Press.

Borras Jr, Saturnino .M. and Franco, Jennifer C. 2010. Contemporary discourses and contestations around pro-poor land policies and land governance. Journal of Agrarian Change 10.1: 1-32.

Borras, Saturnino M., Hall, Ruth, Scoones, lan, White, Ben and Wolford, Wendy. 2011. Towards a better understanding of global land grabbing: An editorial introduction. The Journal of Peasant Studies 38.2: 209-216.

Bush, Simon and Marschke, Melissa. 2014. Making social sense of aquaculture transitions. Ecology and Society 19.3: 50

Campling, Lisa and Colás, Alejandro. 2018. Capitalism and the sea: Sovereignty, territory and appropriation in the global ocean. Environment and planning D: society and space 36.4: 776-794. 
Carr, Edward R. 2013. Livelihoods as Intimate Government: Reframing the logic of livelihoods for development. Third World Quarterly 34.1: 77108.

Childs, John R. and Hicks, Christina C. 2019. Securing the blue: political ecologies of the blue economy in Africa. Journal of Political Ecology26.1: 323-340.

Cooke, S. J., Allison, E.H, Beard Jr. T.D et al. 2016. On the sustainability of inland fisheries: finding a future for the forgotten. Ambio 45: 753764.

De Haan, Leo and Zoomers, Annelies. 2005. Exploring the frontier of livelihoods research. Development and change 36.1: 27-47.

Downing, John A. 2009. Global limnology: Up-scaling aquatic services and processes to planet Earth. Internationale Vereinigung für theoretische und angewandte Limnologie: Verhandlungen 30.8: 1149-1166.

Downing, John A. 2014. Limnology and oceanography: two estranged twins reuniting by global change. Inland Waters 4.2: $215-232$.

Dressler, Wolfram H. and Fabinyi, Michael 2011. Farmer Gone Fish'n? Swidden Decline and the Rise of Grouper Fishing on Palawan Island, the Philippines. Journal of Agrarian Change 11.4: 536-555.

Eder, James F. 1993. Family farming and household enterprise in a Philippine community, 1971-1988: persistence or proletarianization? The Journal of Asian Studies 52.3: 647-671.

Ellis, Frank, 2000. Rural livelihoods and diversity in developing countries: Evidence and Policy Implications. Oxford: Oxford University Press.

Fairhead, J., Leach, M. and Scoones, I., 2012. Green grabbing: a new appropriation of nature? Journal of Peasant Studies, 39(2), pp.237-261.

Farrington, John D. 2005. De-development in eastern Kyrgyzstan and persistence of semi-nomadic livestock herding. Nomadic Peoples 9: 1-2: 171-197.

Féaux de la Croix, Jeanne. 2011. Moving metaphors we live by: water and flow in the social sciences and around hydroelectric dams in Kyrgyzstan. Central Asian Survey 30.3-4: 487-502.

Féaux de la Croix, Jeanne. 2016. Iconic Places in Central Asia: The Moral Geography of Dams, Pastures and Holy Sites. New York: Columbia University Press/Transcript Verlag.

Foley, Paul and Mather, Charles. 2019. Ocean grabbing, terraqueous territoriality and social development. Territory, Politics, Governance 7.3: 297-315.

Fumagalli, Matteo. (2015) 'The Kumtor gold mine and the rise of resource nationalism in Kyrgyzstan ' Central Asia Economic Paper Series 16, George Washington University, Central Asia Program.

Funge-Smith, Simon. 2018. Review of the state of world fishery resources: inland fisheries. FAO Fisheries and Aquaculture Circular No. C942 Rev. 3. Rome: The Food and Agriculture Organization of the United Nations.

Funge-Smith, Simon and Bennett, Abigail. 2019. A fresh look at inland fisheries and their role in food security and livelihoods. Fish and Fisheries https://doi.org/10.1111/faf.12403 20: 1176-1195.

Gereffi, Gary. 1999. International trade and industrial upgrading in the apparel commodity chain. Journal of International Economics 48.1: 3770 .

Gereffi, Gary, Humphrey, John and Sturgeon, Timothy. 2005. The governance of global value chains. Review of International Political Economy 12.1: 78-104.

Graham, Norman, Pueppke, Steven, G. and Uderbayev, Talgat, 2017. The current status and future of Central Asia's fish and fisheries: Confronting a wicked problem. Water 9.9: 701. 
Gullette, David and Heathershaw, John. 2015. The affective politics of sovereignty: reflecting on the 2010 conflict in Kyrgyzstan. Nationalities Papers 43. 1: 122-139.

Hall, D., P. Hirsch, and T.M. Li. 2011. Powers of exclusion: Land dilemmas in Southeast Asia. Honolulu: University of Hawai'i Press.

Hap, Navy, Seng, Leang and Chuenpagdee, Ratana. 2006. Socioeconomics and livelihood values of Tonle Sap Lake fisheries. Phnom Penh: IFReDI.

Harvey, David. 2014. Seventeen Contradictions and the End of Capitalism. Oxford: Oxford University Press.

Hornborg, Alf and Crumley, Carole L. (eds). 2016. The World System and the Earth System: global socioenvironmental change and sustainability since the Neolithic, Abingdon: Routledge.

Horrocks-Taylor, Joseph. 2018. Dirty Water, Muddied Politics: Hybridisation of Local and National Opposition to Kumtor Mine, Kyrgyzstan. Land 7.2: 42.

Horwitz, Pierre, Michael Lindsay, and Moira O'Connor. 2001. Biodiversity, endemism, sense of place, and public health: inter-relationships for Australian inland aquatic systems. Ecosystem Health 7.4: 253-265.

Idrobo, Carlos J. and Johnson, Derke S. 2019. Livelihood transitions and social wellbeing on the Atlantic Forest Coast of Brazil. Maritime Studies 19: 67-79.

Ismailbekova, Aksana. 2017. Blood ties and the native son: poetics of patronage in Kyrgyzstan. Bloomington: Indiana University Press. Jenish, Nazgul. 2017. Tourism sector in Kyrgyzstan: trends and challenges. Bishkek: University of Central Asia, Institute of Public Policy and Administration Working Paper 42.

Kadfak, Alin. 2019. More than Just Fishing: The Formation of Livelihood Strategies in an Urban Fishing Community in Mangaluru, India. The Journal of Development Studies: https://www.tandfonline.com/doi/full/10.1080/00220388.2019.1650168?scroll=top\&needAccess=true Kawanabe, Hiroya, Nishino, Machiko and Maehata, Masayoshi (eds). 2012. Lake Biwa: Interactions between Nature and People. Netherlands: Springer.

Kelly, Philip F. 2011. Migration, agrarian transition, and rural change in Southeast Asia: Introduction. Critical Asian Studies 43.4: 479-506.

King, Tanya J. and Robinson, Gary (eds). 2019. At Home on the Waves: Human Habitation of the Sea from the Mesolithic to Today. New York: Berghahn Books.

Knudsen, Magne. 2012. Fishing families and cosmopolitans in conflict over land on a Philippine island. Journal of Southeast Asian Studies43.3: 478-499.

Knudsen, M., 2016. Poverty and beyond: Small-scale fishing in overexploited marine environments. Human ecology 44.3: 341-352.

Kozhokulov, Sadyrbek, Chen, Xi, Yang, Degang et al. 2019. Assessment of Tourism Impact on the Socio-Economic Spheres of the Issyk-Kul Region (Kyrgyzstan). Sustainability 11.14: 3886.

Kustareva, L.A. and Naseka, Alexander M., 2015. Fish diversity in Kyrgyzstan: Species composition, fisheries and management problems. Aquatic Ecosystem Health \& Management 18.2: 149-159.

Kumtor (2019) ‘Contribution to Economy': https://www.kumtor.kg/en/media-relations/contribution-to-the-kyrgyz-economy/

Kuwahara, Sueo, Ozaki, Takahiro, Nishimura, Akira. 2007. Transperipheral Networks: Bullfighting and Cattle Culture in Japan's Outer Islands. Shima: The International Journal of Research into Island Cultures 1.2: 1-13

Lonely Planet. 2019. Pearl of Kyrgyzstan and Salbuurun Festival in Issyk-Kul. Retrieved October 2019 at:

https://www.lonelyplanet.com/kyrgyzstan/tours/pearl-of-kyrgyzstan-and-salbuurun-festival-in-issyk-kul/a/pa-tou/v-70926P6/356887 
Lynch, Abigail J., Cooke, Steven, Deines, Andrew M. et al. 2016. The social, economic, and environmental importance of inland fish and fisheries. Environmental Reviews 24.2: 115-121.

Martin, Sarah M. and Lorenzen, Kai. 2016. Livelihood diversification in rural Laos. World Development, 83: 231-243.

McLean, Jessica E. 2015. Beyond the pentagon prison of sustainable livelihood approaches and towards livelihood trajectories approaches. Asia Pacific Viewpoint 56.3: 380-391.

Mikkola, Heimo. 2012. Implication of Alien Species Introduction to Loss of Fish Biodiversity and Livelihoods on Issyk-Kul Lake in Kyrgyzstan. In: Gbolagade Akeem Lameed (editor), Biodiversity Enrichment in a Diverse World, IntechOpen. Available from: https://www.intechopen.com/books/biodiversity-enrichment-in-a-diverse-world/implication-of-alien-species-introduction-to-loss-of-fishbiodiversity-and-livelihoods-on-issyk-kul-

Neiland, A.E. and C. Béné (eds). 2008. Tropical river fisheries valuation: background papers to a global synthesis. The World Fish Center Studies and Reviews. Penang: The World Fish Center.

Nippon Koei (2009) Issy-kul sustainable development project, Kyrgyz Republic ADB TA No. 7228 v5

Niyazov, B. 2007. Condition of fish farming in the Kyrgyz Republic in 2006. Paper presented at the National Workshop on Fisheries and Aquaculture in the Kyrgyz Republic: Status and Prospects to increase the Contribution of the Sector to Food Security, EU/FAO/Government of Kyrgyzstan, Bishkek, 12 September 2007.

Palmer, Nicola. 2009. Kyrgyz tourism at Lake Issyk-Kul: Legacies of Pre-Communist and Soviet Regimes. In Singh, Shalini (ed). Domestic tourism in Asia: diversity and divence, London, Earthscan: 181-196.

Petric, Boris. 2015. Where are All Our Sheep? Kyrgyzstan, a Global Political Arena, New York: Berghahn Books.

Pickles, John and Smith, Adrian, 2016. Articulations of capital: global production networks and regional transformations. Hoboken: John Wiley \& Sons.

Porter, Brooke A., Mark B. Orams, and Michael Lück. 2015. Surf-riding tourism in coastal fishing communities: A comparative case study of two projects from the Philippines. Ocean \& Coastal Management 116: 169-176.

Reeves, Madeleine. 2014. Border work: Spatial lives of the state in rural Central Asia. Ithaca: Cornell University Press.

Rigg, Jonathan. 2006. Land, farming, livelihoods, and poverty: rethinking the links in the rural South. World Development 34.1: $180-202$.

Rigg, Jonathan, Salamanca, Albert and Parnwell, Michael. 2012. Joining the dots of agrarian change in Asia: A 25 year view from Thailand. World Development 40.7: 1469-1481.

Rigg, Jonathan and Salamanca, Albert. 2017. Aggregate trends, particular stories: tracking and explaining evolving rural livelihoods in Southeast Asia. In McGregor, Andrew, Law, Lisa and Miller Fiona (eds) Routledge Handbook of Southeast Asian Development. London: Routledge: 39-52.

Romanovsky, V.V. 2002. Hydrobiology of Lake Issyk-Kul. In Klerkx, J. and Imanackunov, B. (eds) Lake Issyk-Kul: Its Natural Environment. Dordecht: Kluwer Academic Press: 27-44.

Ruddle, Kenneth and Satria, Arif (eds.). 2010. Managing Coastal and Inland Waters: Pre-existing aquatic management systems in Southeast Asia. New York: Springer Science \& Business Media.

Sagynbekova, Lira. 2017. Environment, rural livelihoods, and labor migration: A case study in central Kyrgyzstan. Mountain research and development 37.4: 456-464.

Samakov, Aibeck and Berkes, Fikret. 2017. Spiritual commons: sacred sites as core of community-conserved areas in Kyrgyzstan. International Journal of the Commons 11.1: 422-444. 
Song, A.M., Bower, S.D., Onyango, P., et al. Intersectorality in the governance of inland fisheries. Ecology and Society 23.2: 17.

Tezzo, Xavier, Belton, Ben, Johnstone, Gareth and Callow, Martin. 2018. Myanmar's fisheries in transition: Current status and opportunities for policy reform. Marine Policy 97: 91-100.

Thorpe, Andy and van Anrooy, Raymond, 2009. Inland fisheries livelihoods in Central Asia: policy interventions and opportunities. Food and Agriculture Organization of the United Nations.

Thorpe, Andy, van Anrooy, Raymond., Niyazov, B.N et al. 2009. The collapse of the fisheries sector in Kyrgyzstan: an analysis of its roots and its prospects for revival. Communist and Post-Communist Studies 42.1: 141-163.

Tubtim, Tubtim and Hirsch, Philip. 2017. Decropping the Southeast Asian countryside. Routledge Handbook of Southeast Asian Development: 271-280

Werner, Marion. 2018. Geographies of production I: Global production and uneven development. Progress in Human Geography.0309132518760095.

Wooden, Amanda E. and Féaux de la Croix, Jeanne. 2015. The 'great future of the country'? Dams and hydroelectricity discourses in Kyrgyzstan. In Freedman, Eric and Neuzil, Mark (eds) Environmental Crises in Central Asia, London: Routledge: 70-82.

World Bank 2019. Kyrgyz Republic. Retrieved October 2019 from: https://data.worldbank.org/country/kyrgyz-republic 